\title{
Antioxidant Activity and Cytotoxicity Effect of Cocoa Beans Subjected to Different Processing Conditions in Human Lung Carcinoma Cells
}

\author{
Deborah Bauer, ${ }^{1}$ Joel Pimentel de Abreu, ${ }^{1}$ Hilana Salete Silva Oliveira, ${ }^{2}$ \\ Aristoteles Goes-Neto, ${ }^{2}$ Maria Gabriela Bello Koblitz, ${ }^{1,3}$ and Anderson Junger Teodoro ${ }^{1,3}$ \\ ${ }^{1}$ Nutritional Biochemistry Core, Federal University of Rio de Janeiro State, Avenida Pasteur 296-Urca, \\ 22290-240 Rio de Janeiro, RJ, Brazil \\ ${ }^{2}$ Graduate Program in Biotechnology, State University of Feira de Santana, Avenida Transnordestina, S/N, Novo Horizonte, \\ 44036-900 Feira de Santana, BA, Brazil \\ ${ }^{3}$ Food and Nutrition Graduate Program, Nutritional Biochemistry Core, Federal University of Rio de Janeiro State, \\ Avenida Pasteur 296-Urca, 22290-240 Rio de Janeiro, RJ, Brazil
}

Correspondence should be addressed to Anderson Junger Teodoro; atteodoro@gmail.com

Received 30 October 2015; Revised 10 February 2016; Accepted 17 February 2016

Academic Editor: Denis Delic

Copyright (C) 2016 Deborah Bauer et al. This is an open access article distributed under the Creative Commons Attribution License, which permits unrestricted use, distribution, and reproduction in any medium, provided the original work is properly cited.

Lung cancer is a common malignancy in men and the second leading cause of cancer-related mortality in men in the western world. Phenolic cocoa ingredients have a strong antioxidative activity and the potential to have a protective effect against cancer. In the present study, we have evaluated the influence of cocoa beans subjected to different processing conditions on cell viability and apoptosis of human lung cancer cells (A549). We measured the viability of lung cells treated with cocoa beans, unroasted slates (US), roasted slates (RS), unroasted well fermented (UWF) cocoa, and roasted well fermented (RWF) cocoa for $24 \mathrm{~h}$. Using an MTT assay, we observed a decrease in the viability of A549 cells after treatment with cocoa bean extracts. Flow cytometer analysis revealed that cocoa beans increased the percentage of cells in sub- $\mathrm{G}_{1}$ phase and promoted up to twofold increase of apoptotic cells when compared to the control group. Taken together, the present study suggests that cocoa beans may have a protective effect against lung cancer.

\section{Introduction}

Lung cancer is a major health concern since it is one of the leading causes of death worldwide [1,2]. It is estimated that the annual incidence rate is nearly 1.23 million. In Brazil, it is the second most frequent type of cancer and it has the highest mortality rate, due to late diagnosis and the aggressiveness of the tumor type. In $80-90 \%$ of cases, it is caused by smoking and exposure to pollutants. The existing therapeutic strategies for cell lung cancer include surgery, radiotherapy, chemotherapy, and physical therapy. The survival rate of nonsmall-cell lung cancer patients is less than $1 \%[3,4]$.

The proposals that cancer might be preventable, and that food and nutrition might influence the risk of cancer, were first made in the 19th and 20th centuries. Throughout recorded history, wise choices of food and drink, and of habitual behavior, have been recommended as a protective measure against cancer [5]. Researchers are still unsure about the role of diet in lung cancer. Bright yellow-orange beta-carotene is one of a number of carotenoids thought to have anticancer activity even greater than vitamin A. Other possible lung protectors are foods high in bioactive compounds such as vitamin $\mathrm{C}$ and other antioxidants present in fruits and vegetables. These nutrients may protect lung linings but cannot totally prevent damage [6].

Among the different bioactive compounds, phenolic compounds from fruits and vegetables have gained much attention over the years because of their antioxidant activity that indirectly reflects their potential effects on human health $[7,8]$. Some studies reported that phenolic compounds found 
in cocoa beans may present different properties such as antioxidant, anticarcinogenic, and antiradical activities [911]. Polyphenols are the main antioxidant-active constituents of cocoa. Flavanols and procyanidins have previously been identified as the active antioxidant agents of cocoa [12]. The polyphenol content of cocoa products depends on many factors, especially the cultivated variety and the postharvest handling that includes fermentation, drying, and roasting of the beans and nibs. There is evidence that fermentation and roasting of the beans tend to reduce their flavanol content $[13,14]$. The antioxidant activity of the phenolic compounds is primarily due to their redox properties that allow them to act as reducing agents, hydrogen donors, and scavengers of reactive oxygen species (ROS) and metal ions [8, 15-17]. The emergence of natural extracts with antioxidant properties may help reduce the current dependence on synthetic drugs.

Potential mechanisms for cancer prevention of bioactive compounds include prevention of DNA adduct formation enhanced carcinogen elimination, inhibition of inflammatory processes, and a direct cytotoxic effect on tumour cells [18-20]. In line with efforts to balance the conservation of biodiversity and encourage the controlled exploitation of plant resources for economic gain, especially in biopharming, waste of valuable resources should be minimized [17]. The aim of this study was to evaluate and compare the antioxidant activity of cocoa beans classified as slate, roasted, and unroasted with well fermented beans submitted to the same processing and their cytotoxic effects on human lung carcinoma cell line (A549).

\section{Methods}

2.1. Samples and Extractions. Samples of cocoa beans, unroasted slates (US), roasted slates (RS), unroasted well fermented (UWF) cocoa, and roasted well fermented (RWF) cocoa were harvested and preprocessed (fermented and dried) in the cocoa producing region of Ilhéus (Bahia, Brazil). These samples were classified according to their fermentation status and donated by a company of the cocoa sector from the same region. At least three different lots of each cocoa class were mixed to form the samples used in this study. The roasting as well as the fine grinding of all beans was carried out in the State University of Feira de Santana (BA). All samples were kept at $-5^{\circ} \mathrm{C}$ and sent to the Functional Foods and Biotechnology Laboratory of the Federal University of Rio de Janeiro State (UNIRIO), where all analyses were conducted.

2.2. Extraction of Samples. The samples of cocoa were extracted with 3 different solution extractors: methanol (I), methanol 50\% (II), and methanol 50\%: acetone 70\% (1:1) (III). $1.25 \mathrm{~g}$ of sample was weighed and suspended in $10 \mathrm{~mL}$ of extracting solution for 1 hour under stirring, protected from light. The crude extracts were filtered and completed in $25 \mathrm{~mL}$ with distilled water. For cellular analysis, $1.25 \mathrm{~g}$ of each sample was weighed and suspended in saline solution (PBS) at $2 \%$ dimethyl sulfoxide (DMSO).
2.3. Total Phenolic Assay. Total phenolic content of the extracts was determined according to the Folin-Ciocalteu method as described by Singleton and Rossi [21] with minor modifications. Aliquots of $0.5 \mathrm{~mL}$ of the extracts were added to $2.5 \mathrm{~mL}$ of Folin-Ciocalteu reagent and $2.0 \mathrm{~mL}$ of $4 \%$ sodium carbonate solution and the mixture was allowed to rest for 2 hours in the dark. Measurements were performed at $750 \mathrm{~nm}$ in triplicates, applying a Turner ${ }^{\circledR} 340$ spectrophotometer. Gallic acid, in the concentration range of $0-100 \mathrm{mg} / \mathrm{mL}^{-1}$, was used to construct a calibration curve. The concentration of total phenolic compounds in the extract was expressed as gallic acid equivalents, which reflect the phenolic content as the amount of gallic acid in $\mathrm{mg} / 100 \mathrm{~g}$ dry weight of the samples.

\subsection{Antioxidant Activity Analyses}

2.4.1. DPPH Assay. Aliquots of $0.5 \mathrm{~mL}$ of the extracts were mixed with $2.5 \mathrm{~mL}$ DPPH methanolic solution $(0.06 \mathrm{mM})$ and allowed to react for 1 hour, in the dark. Measurements were performed at $515 \mathrm{~nm}$ applying a Turner 340 spectrophotometer. The analysis was performed in triplicates; the decline in the DPPH radical absorbance concentration caused by the extracts was compared to a trolox standard. The results were expressed as $\mu \mathrm{mol}$ trolox equivalents/g dry basis. [22].

\subsubsection{Trolox Equivalent Antioxidant Capacity (ABTS/TEAC).} The $\mathrm{TEAC}^{\bullet+}$ cation was prepared by mixing a TEAC stock solution ( $7 \mathrm{mM}$ in water) with $2.45 \mathrm{mM}$ potassium persulfate. This mixture was allowed to stand for 16 hours at room temperature until the reaction was completed and the absorbance was stable.

The antioxidant capacity assay was carried out by the improved ABTS/TEAC method as described by Rufino et al. [23]. TEAC solution $(2.5 \mathrm{~mL})$ was added to extracts or commercial antioxidant (trolox) and mixed thoroughly. Absorbance was recorded at $734 \mathrm{~nm}$ during $6 \mathrm{~min}$. Aliquots of 5,10 , and $20 \mu \mathrm{L}$ of the extracts were tested and their volume was completed to $0.5 \mathrm{~mL}$ with water. Results were expressed as $\mu \mathrm{mol}$ trolox/g dry basis.

2.4.3. Ferric Reducing Ability (FRAP). The extracts were measured for antioxidant activity by FRAP according to Rufino et al. [24]. Aliquots of $2.7 \mathrm{~mL}$ of TPTZ reagent (ferric 2,4,6tripyridyl-s-triazine) were mixed with $0.5 \mathrm{~mL}$ of sample extract (aliquots 5,10 , and $20 \mu \mathrm{L}$ ). After $30 \mathrm{~min}$ at $37^{\circ} \mathrm{C}$ temperature, the absorbance was read at $595 \mathrm{~nm}$. The antioxidant capacity (FRAP) was expressed as $\mathrm{Fe}^{3+}$ equivalents ( $\mu \mathrm{mol}$ $\mathrm{Fe}^{3+} / \mathrm{g}$ dry basis).

2.4.4. Cell Culture and Treatment Protocol. Cell lines were obtained from the Rio de Janeiro Cell Bank which certified their identity and quality (INMETRO, Rio de Janeiro, RJ, Brazil). Human lung carcinoma cell line (A549) was plated in $25 \mathrm{~cm}^{2}$ tissue culture flasks $\left(5.0 \times 10^{6}\right.$ cells/flask $)$ and maintained routinely in Dulbecco's Modified Eagle's Mediumhigh glucose (DMEM) supplemented with 10\% Fetal Bovine Serum (FBS) and 1\% Penicillin (PS), pH 7.4, under 5\% $\mathrm{CO}_{2}$ 
atmosphere. Stock flasks were grown to $70 \%$ confluence and subcultured routinely. Medium renewal was done 3 times weekly. For each experiment, cells were seeded at $3.5 \times$ $10^{5}$ cells $/ \mathrm{cm}^{2}$ and $2 \times 10^{4}$ cells $/ \mathrm{cm}^{2}$ densities in 6 -well plates and 96-well plates for cell cycle and cell proliferation analyses, respectively. After $24 \mathrm{~h}$, medium was removed and cells were treated with increasing concentrations of cocoa nibs extract $(100$ to $10000 \mu \mathrm{g} / \mathrm{mL})$ dissolved in DMEM. The controls, DMEM and DMEM + 2\% DMSO, were included on each plate. The cells were then incubated for 48 hours.

2.4.5. Cell Viability. Cell viability was monitored by MTT assay (Amresco, Solon, OH). MTT (3-(4,5-dimethylthiazol2-yl)-2,5-diphenyltetrazolium bromide) is a pale yellow substrate that is reduced by living cells to yield a dark blue formazan product. This requires active mitochondria, and even recently dead cells do not reduce significant amounts of MTT. Exponentially growing cells were adjusted to $2.0 \times 10^{4} / \mathrm{cm}^{2}$ with DMEM, plated in 96-well plates (Corning, Tewksbury, MA) at $200 \mu \mathrm{L} /$ well and incubated for $24 \mathrm{~h}$ according to the routine procedure. The cells were then incubated with cocoa nibs unroasted slates (US), roasted slates (RS), unroasted well fermented (UWF) cocoa, and roasted well fermented (RWF) cocoa (5-10 mg/mL) for $48 \mathrm{~h}$ (6 wells for each sample). Each well was also incubated with MTT $(10 \mu \mathrm{L} /$ well; $5 \mathrm{~g} / \mathrm{mL}$ ) for $4 \mathrm{~h}$. After $85 \mu \mathrm{L} /$ well the liquid was removed and $50 \mu \mathrm{L} /$ well sodium dodecyl sulfate was added to dissolve the solid residue. Finally, the absorbance was measured using a microplate reader (POLARIS, CELER ${ }^{\circledR}$ ) at $570 \mathrm{~nm}$. The cell proliferation inhibition rate (CPIR) was calculated using the following formula: CPIR $=(1-$ average value of experimental group/average value of control group) $\times 100 \%$.

2.4.6. Cell Cycle Analysis. Cells were rinsed briefly with calcium and magnesium-free phosphate-buffered saline and detached with trypsin at room temperature. After centrifugation, the cells were washed twice with phosphatebuffered saline; cells were resuspended in $500 \mu \mathrm{L}$ of ice-cold Vindelov solution [25] containing $0.1 \%$ Triton X-100, $0.1 \%$ citrate buffer, $0.1 \mathrm{mg} / \mathrm{mL}$ RNase, and $50 \mathrm{mg} / \mathrm{mL}$ propidium iodide (Sigma Chemical Co., St. Louis, MO). After $15 \mathrm{~min}$ of incubation, cell suspension was analysed for DNA content by flow cytometry using a FACSCalibur flow cytometer (Becton Dickinson, Mountain View, CA). The relative proportions of cells with DNA content indicative of apoptosis $(<2 n), G_{0} / G_{1}$ diploid $(2 n), S$ (phase $>2 n$ but $<4 n$ ), and $G_{2} / M$ phase $(4 n)$ were obtained and analyzed using the CellQuest WinMDI 2.9. The percentage of cell population at a particular phase was estimated with FlowJo software. Cell dissociation procedure does not affect fluorescence under the experimental conditions that were used in this study or in any other studies of which we are aware. Nuclei of viable cells were gated according to FL-2W $\times$ FL2-A relation.

2.4.7. Apoptosis Assay. To measure the rate of apoptosis, the cells were subjected to staining with Annexin V conjugated to FITC (BD Pharmingen, San Diego, CA). The nonadherent cells were collected, and adherent cells were quickly washed

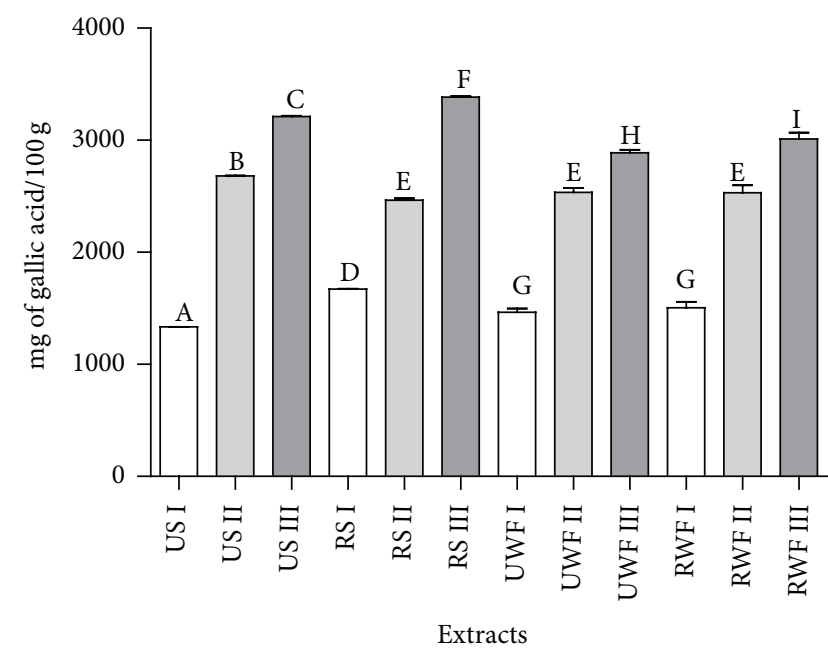

FIgURE 1: Total phenolic compounds of cocoa nibs unroasted slates (US), roasted slates (RS), unroasted well fermented (UWF) cocoa, and roasted well fermented (RWF) cocoa. Extracting solutions: I, methanol; II, methanol 50\%; III, 1/2 50\% methanol:1/2 70\% acetone. Means with different letters differ significantly $(p<0.05$, Tukey's test).

with buffered saline solution (BSS) calcium/magnesium-free and were detached with trypsin/EDTA 0.125\% (Sigma chemical Co., St. Louis, USA) at room temperature. Subsequently, apoptotic and necrotic cells were stained with Annexin VFITC/propidium iodide (PI) (BD Pharmingen, New Jersey, USA) according to the manufacturer's instructions, quantified by flow cytometer (FACSCalibur, BD Bioscience, New Jersey, USA), and analyzed using two specific programs, Cell Quest and FlowJo software.

2.5. Statistical Analysis. Results are presented as mean with the corresponding standard deviation of 3 independent experiments done in triplicates $(n=9)$. Data were analysed with the statistical software GraphPad Prism (version 5.04, GraphPad Software, San Diego, CA) and Statistica (version 7.0, StatSoft Inc., Tulsa, OK). One-way analysis of variance (ANOVA) test with the posttest of Tukey at a confidence level of $95 \%$ was used to test cell viability, cell cycle, and apoptosis.

\section{Results and Discussion}

3.1. Phenolic Compounds and Antioxidant Activity of Cocoa Beans Samples. The method that yielded higher phenolic extracts was the one using acetone, in all samples tested, as can be observed in Figure 1. Dreosti [26] reported that $60 \%$ of the total phenolics in raw cocoa beans are flavanol monomers (epicatechin and catechin) and procyanidin oligomers (dimer to decamer) [27]. Benayad et al. [28], Cheng et al. [29], and Boulekbache-Makhlouf et al. [30] have shown that the use of acetone, when compared to the use of other polar organic compounds, potentiated the extraction of flavonoids and flavonols from different plant materials. In addition, extraction of procyanidins from cocoa with acetone solutions has been successfully accomplished at least since 1999 . 
TABLE 1: Effect of extracts of cocoa, cocoa nibs roasted slates (RS), and unroasted well fermented (UWF) cocoa (5-10 mg/mL) on cell cycle progression in human lung cancer cell line after 48 hours.

\begin{tabular}{cccrr}
\hline & Cell cycle phase & CT & $5 \mathrm{mg} / \mathrm{mL}$ & $10 \mathrm{mg} / \mathrm{mL}$ \\
\hline \multirow{4}{*}{ RS } & sub-G $-G_{1}$ & $6.65 \pm 1.00$ & $55.65 \pm 0.49$ & $77.10 \pm 2.26$ \\
& $\mathrm{G}_{0} / \mathrm{G}_{1}$ & $75.75 \pm 4.45$ & $30.65 \pm 0.92^{*}$ & $20.63 \pm 0.90^{*}$ \\
& $\mathrm{~S}$ & $5.40 \pm 0.77$ & $4.89 \pm 0.16$ & $0.74 \pm 0.40^{*}$ \\
& $\mathrm{G}_{2} / \mathrm{M}$ & $7.68 \pm 1.77$ & $6.73 \pm 0.38$ & $0.70 \pm 0.64^{*}$ \\
\hline \multirow{3}{*}{$\mathrm{UWF}$} & $\mathrm{sub}-\mathrm{G}_{1}$ & $1.37 \pm 0.29$ & $13.55 \pm 2.62^{*}$ & $50.28 \pm 7.09^{* *}$ \\
& $\mathrm{G}_{0} / \mathrm{G}_{1}$ & $75.80 \pm 6.02$ & $25.65 \pm 7.57^{*}$ & $21.78 \pm 5.35^{*}$ \\
& $\mathrm{~S}$ & $5.61 \pm 1.17$ & $2.64 \pm 1.58^{*}$ & $2.20 \pm 1.01^{*}$ \\
& $\mathrm{G}_{2} / \mathrm{M}$ & $11.58 \pm 3.54$ & $33.95 \pm 3.04^{* *}$ & $16.08 \pm 4.01^{*}$ \\
\hline
\end{tabular}

Results are expressed as the percentage of total cells. The data represent mean \pm SD values of triplicate experiments. Tukey's test; ${ }^{*} p<0.05 ;{ }^{* *} p<0.01$.

The present work found amounts of phenolic substances (Table 1) compatible with the results displayed by Kadow et al. [31] for both raw and "fermentation-like" treated samples. Unprocessed cocoa beans usually present a high phenolic content of about 12-18\% (dry weight) [32]. The processing of raw cocoa includes a number of stages and each stage in the processing alters cocoa's chemistry and composition [11]. When extractor III was considered, there were significant differences among all samples tested and slates showed higher phenolic content when compared to well fermented samples. Generally, it is expected that well fermented beans show lower phenolic contents, because low mass phenols are related to astringency and anthocyanins are related to the purple color of unfermented beans, both considered undesirable characteristics in chocolate $[33,34]$.

Figures 2(a)-2(c) clearly show that the overall higher values were obtained for the DPPH method, followed by TEAC and FRAP, respectively. The slate samples showed higher antioxidant activity compared to well fermented beans or nibs. All these findings were in agreement with previous results as it was expected to obtain higher antioxidant activity in extracts with higher concentrations of phenolic compounds [14, 35-37].

The roasted slate (RS) samples showed a decrease in antioxidant activity after fermentation. Roasting is considered one of the processing steps of the cocoa nibs that leads to the loss of phenolic compounds and should cause a decrease in the antioxidant activity, as may be seen when comparing UWF and RWF samples (Figure 2). It is possible that, during roasting, while phenolic compounds are degraded, other antioxidant potential compounds are formed through the Maillard reaction, especially reductones and melanoidins [38, 39]. The reason why this formation may have been significant in slates but not in well fermented beans is probably related to the different compositions of these two samples before the roasting process.

FRAP assay showed a decrease in antioxidant activity after roasting. According to Apak et al. [40], FRAP methodology is not capable of measuring the antioxidant activity of compounds in complex matrix, since it takes more time to perform the analysis of antioxidant function, and not all antioxidants have the specific ability to reduce iron [41].

Recovery of antioxidant compounds from plant materials is typically accomplished through different extraction techniques, taking into account their chemistry and uneven distribution in the plant matrix. These compounds tend to present different polarities as well as other variable characteristics. Thus, the solubility in a particular solvent is a unique feature of the phytochemicals to be taken into account. Methanol and solutions of 50\% methanol in water are commonly applied solvents that efficiently extract phenolic compounds. Methanol and acetone are also suitable solvents for anthocyanin extraction from various raw materials [4244], and acetone-water mixtures have been suggested to grant better extraction results of procyanidins and phenols when compared with other extractors [45].

It is now recognized that diet and nutrients play an import role in cancer development and progress, with many dietary components found to be associated with cancer risk. However, almost all the clinical intervention trials with isolated nutrients, such as vitamin A, vitamin E, vitamin C, and phenolic compounds supplements, failed to demonstrate their protective effects against cancer. Due to the complexity of cocoa matrix, it is very difficult to characterize all components and even say which major component is responsible for the cytotoxic effect, due to the synergistic and antagonistic effects.

\subsection{Cells Results}

3.2.1. Effect of Cocoa Extracts on Cell Viability. The slate nibs were the supplement which caused the largest decrease in viability compared to control (34.45\%, Figure 3$)$, while cells exposed to US had the highest percentage of viability, $78.07 \%$, at a concentration of $10 \mathrm{mg} / \mathrm{mL}$ (Figure 3(b)). However, surprisingly, crisp sample obtained higher potential reduction in cell viability (Figure 3(c)), with cell viability of $77.15 \%$ $(5000 \mu \mathrm{g} / \mathrm{mL})$ and $63.55 \%(10.000 \mu \mathrm{g} / \mathrm{mL})$.

Well fermented cocoa bean extract decreased the number of viable A549 cells within 48 hours. In UWF sample, cell viability decreased from the concentration of $100 \mu \mathrm{g} / \mathrm{mL}$ by $45 \%$ compared with the control group $(p<0.05)$ (Figures $4(\mathrm{a})$ and $4(\mathrm{~b}))$. The concentrations that caused the largest decrease in cell viability were 5000 and $10000 \mu \mathrm{g} / \mathrm{mL}$, reduced by $58.77 \%$ and $72.35 \%$, respectively (Figure 3(b)). For RWF sample, the reduction was smaller (Figure 3(c)), with effect only at concentrations of 5000 (83.07\% viable cells) and $10000 \mu \mathrm{g} / \mathrm{mL}$ (72.20\% viable cells). 


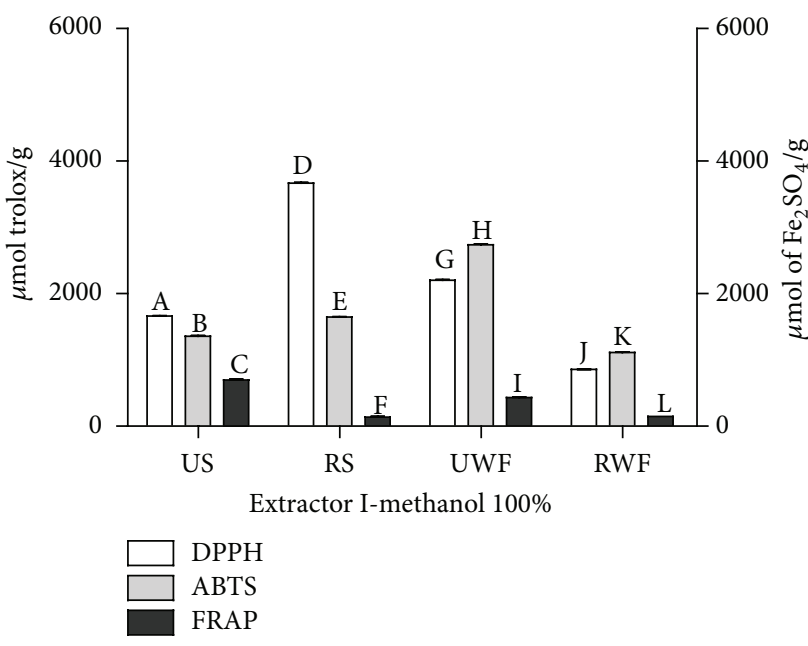

(a)

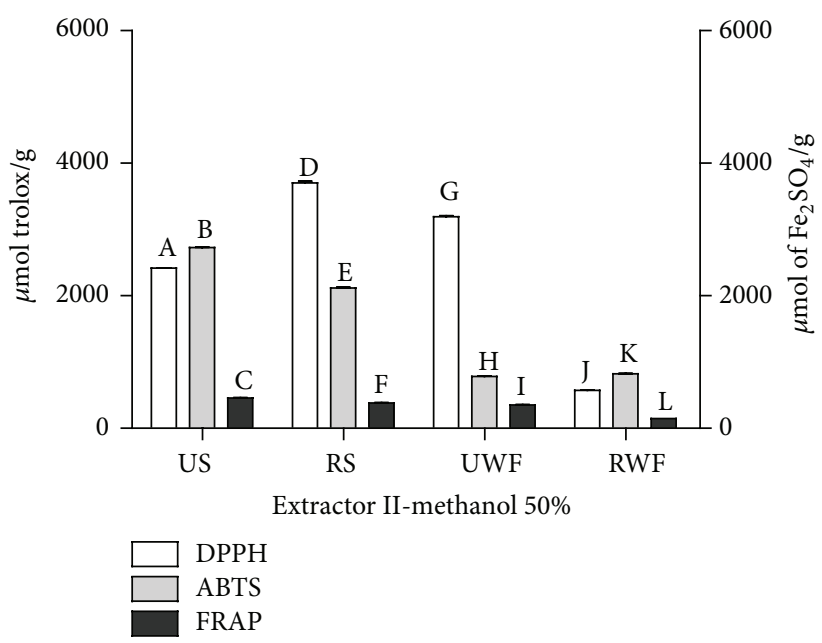

(b)

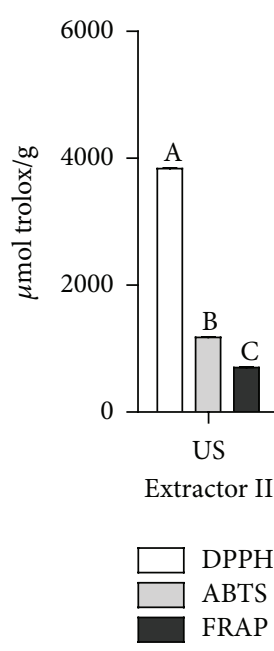

(c)

FIGURE 2: Antioxidant activity of cocoa nibs unroasted slates (US), roasted slates (RS), unroasted well fermented (UWF) cocoa, and roasted well fermented (RWF) cocoa for DPPH, TEAC, and FRAP assays by different extracting solutions (I-III). Means with different letters differ significantly $(p<0.05$, Tukey's test).

Cell culture studies constitute a useful tool to elucidate the molecular mechanisms of action of cocoa extracts and their polyphenolic compounds in different cancer cell lines. It has been shown that cocoa components induced a timedependent regulation of survival/proliferation pathways in HepG2 liver cells [46]. Moreover, a cocoa procyanidin fraction inhibited TPA-induced neoplastic transformation of JB6P+ mouse epidermal cells, COX-2 expression, and phosphorylation of MEK and p90 ribosomal s6 kinase and attenuated activator protein-1 (AP-1) and NF- $\kappa$ B stimulations [47].

The physiological impact of polyphenols depends on their absorption. However, it is important to bear in mind that the most common polyphenols in diet are not necessarily the most bioavailable, since their structure plays an important role. Most native polyphenols in foods are in glycoside form (flavonols, flavones, flavanones, isoflavones, and anthocyanins), together with the less frequent oligomers (proanthocyanidins), which cannot be absorbed in the intestinal mucosa [48]. Through this, we can observe that the sample that most reduced the viability of human lung carcinoma cells was again the sample which had the parent compounds of the modified crude cocoa, such as well fermented sample, and also the sample which has not been roasted, since many bioactive compounds are lost during this processing.

\subsubsection{Effect of Cocoa Extracts on Cell Cycle Progression.} Uncontrolled cell proliferation is a characteristic of cancer [49], and extracts of cocoa beans have been shown to inhibit the proliferation of A549 cells. Previous trials of antioxidant activity and MTT have determined which samples have the greatest potential for use in the analysis of cell cycle and apoptosis. To probe inhibition of cell growth mediated by RS and UWF extracts, we examined the cell cycle by flow cytometry. The effects of the RS and UWF extracts on cell cycle progression in A549 cells are shown in Table 1. 

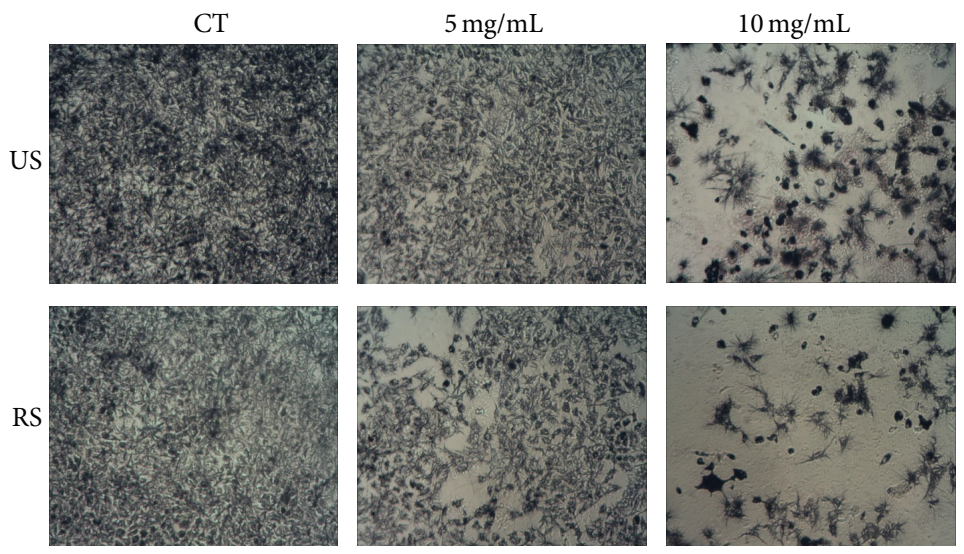

(a)

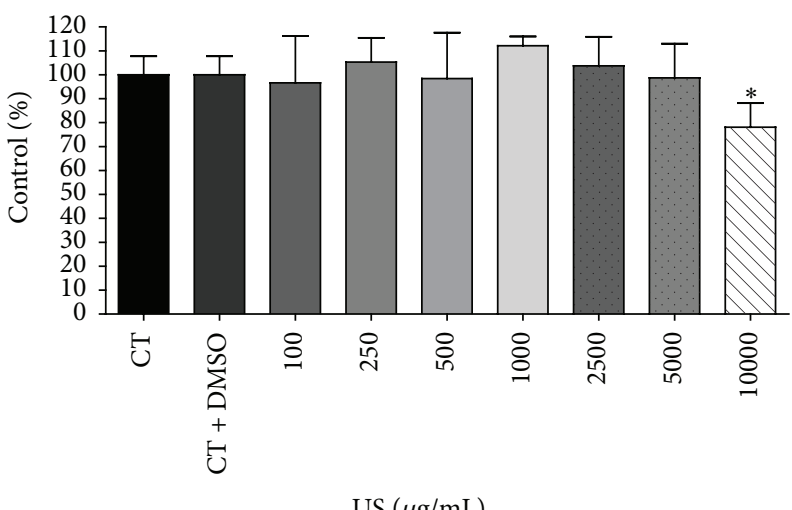

(b)

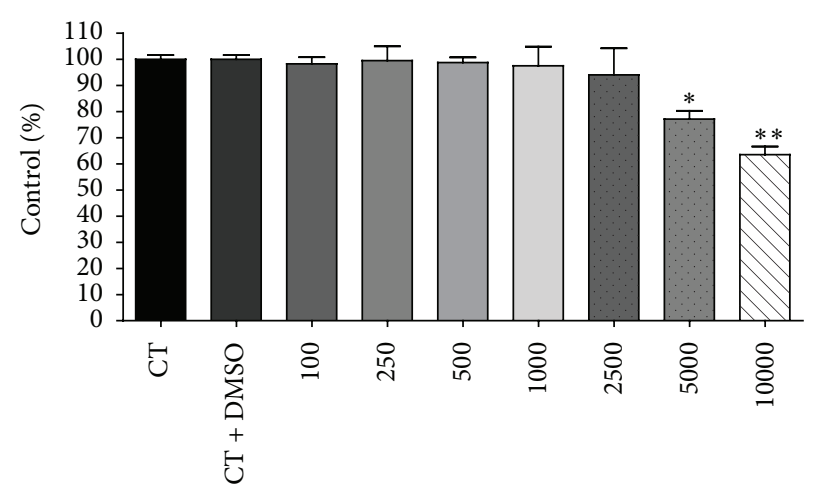

$\operatorname{RS}(\mu \mathrm{g} / \mathrm{mL})$

(c)

FIGURE 3: The effect of unroasted slates (US) and roasted slates (RS) nibs extract in cell control (a). Cocoa nibs US (b) and cocoa nibs RS (c), after forty-eight hours on viability A549 cells after exposure using MTT assays. The results are expressed as mean \pm standard error and significant differences between cells treated with US and RS nibs extract $(100-10000 \mu \mathrm{g} / \mathrm{mL})$ were compared using Tukey's test $\left({ }^{*} p<0.05\right.$; $\left.{ }^{* *} p<0.01\right)$.

After $48 \mathrm{~h}$ of growth, the population control in the sub$\mathrm{G}_{1} \mathrm{G}_{0} / \mathrm{G}_{1}$ phase reached values between 6.65 and $1.37 \%$ and between $75.75 \%$ and $75.80 \%$, respectively. Meanwhile, cells treated in the sub- $\mathrm{G}_{1}$ population increased those treated in $\mathrm{G}_{0} / \mathrm{G}_{1}$ phase decreased in a dose-dependent manner in both treatments. The loss of the ability to regulate the cell cycle is characteristic of cancer cells and results in uncontrollable proliferation. The cell progression through the first gap phase of the cell cycle $\left(G_{1}\right)$ is a step which is frequently disordered in cancer [50].

Treatments with RS resulted in the highest percentage of cells in sub- $\mathrm{G}_{1}(77.01 \%, 10 \mathrm{mg} / \mathrm{mL})$ and in $\mathrm{G}_{0} / \mathrm{G}_{1}(30.65 \%$, $5 \mathrm{mg} / \mathrm{mL}$ ) phases. As the $\mathrm{G}_{0} / \mathrm{G}_{1}$ phase population increased the $G_{2} / M$ phase population of cells decreased, whereas the population of phase $S$ cells showed no difference within $48 \mathrm{~h}$. Treatment with UWF cocoa at a concentration of $10 \mathrm{mg} / \mathrm{mL}$ showed the highest value for sub- $G_{1}(50.27 \%)$ reduction within phases $G_{0} / G_{1}$ and $S$ and an increase in the $G_{2} / M$ phase. Treatment with $5 \mathrm{mg} / \mathrm{mL}$ of UWF cocoa showed the smallest number of cells in sub- $G_{1}$ and the $G_{0} / G_{1}$ phases and therefore a greater cell population in the $G_{2} / M$ phase (33.95\%).
Cocoa-derived pentameric procyanidin (pentamer) caused a $G_{0} / G_{1}$ cell cycle arrest in human breast cancer MDA MB-231, MDA MB-436, MDA MB-468, SKBR-3, and MCF-7 cells and in benzo(a)pyrene-immortalized 184A1N4 and 184B5 cells, whereas normal human mammary epithelial cells in primary culture and spontaneously immortalized MCF-10A cells were resistant [51]. Similarly, procyanidinenriched extracts from cocoa caused growth inhibition with blockade of the cell cycle at $\mathrm{G}_{2} / \mathrm{M}$ phase in human colonic Caco-2 cells [52], and EC induced S phase arrest in the cell cycle progression in LoVo colon cancer cells [53].

Our results indicate that cocoa nibs extracts were able to modify cell cycle. The deregulation in cell cycle control is a fundamental aspect in the development of cancer. Faults in the cell cycle regulation process can cause a greater proliferation of cancer cells. However, the reversal of this process leads to a delay in growth and induces cell death [54].

3.2.3. Apoptosis. We examined the effect of RS and UWF cocoa on apoptotic death in A549 cells. Table 2 shows the percentages of viable, early apoptotic, late apoptotic, and nonapoptotic cells treated with $5 \mathrm{mg} / \mathrm{mL}$ and $10 \mathrm{mg} / \mathrm{mL}$ 

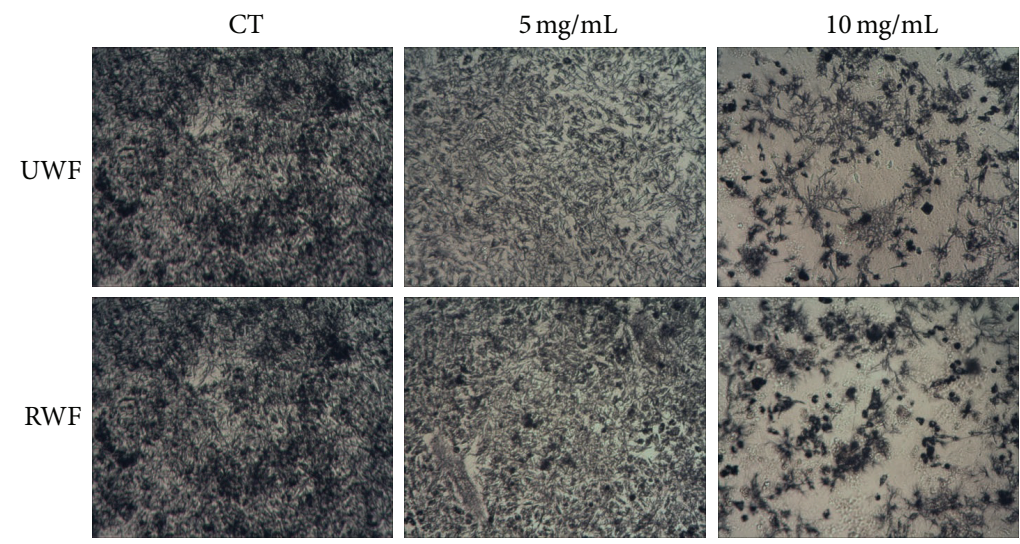

(a)

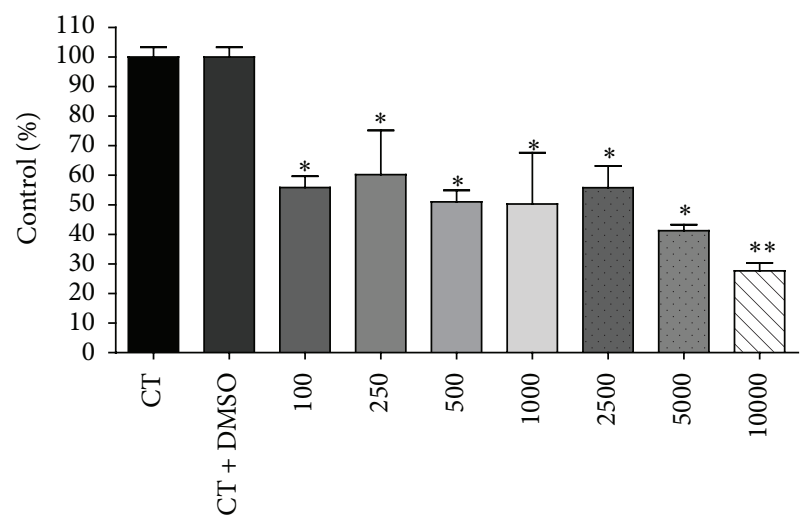

$\operatorname{UWF}(\mu \mathrm{g} / \mathrm{mL})$

(b)

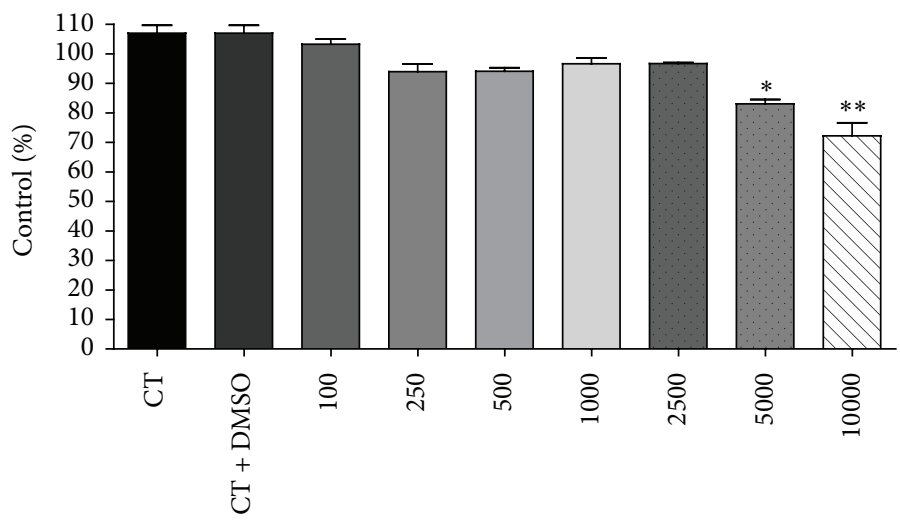

$\operatorname{RWF}(\mu \mathrm{g} / \mathrm{mL})$

(c)

FIGURE 4: The effect of unroasted well fermented (UWF) nibs and roasted well fermented (RWF) nibs extracts in cell control (a). UWF cocoa nibs (b) and RWF cocoa nibs (c), after forty-eight hours on viability A549 cells after exposure using MTT assays. The experiment is expressed as mean \pm standard error and significant differences between cells treated with UWF and RWF nibs extract (100-10000 $\mu \mathrm{g} / \mathrm{mL})$ were compared using Tukey's test $\left({ }^{*} p<0.05 ;{ }^{* *} p<0.01\right)$.

TABLE 2: Effect of extracts of cocoa nibs roasted slates and unroasted well fermented cocoa $(5-10 \mathrm{mg} / \mathrm{mL})$ on programmed cell death in human lung cancer cell line after 48 hours.

\begin{tabular}{|c|c|c|c|c|c|}
\hline \multirow{2}{*}{ Stages of cell death } & \multirow{2}{*}{$\mathrm{CT}$} & \multicolumn{2}{|c|}{$\mathrm{RS}(\mathrm{mg} / \mathrm{mL})$} & \multicolumn{2}{|c|}{ UWF (mg/mL) } \\
\hline & & 5 & 10 & 5 & 10 \\
\hline $\begin{array}{l}\text { Viable cells } \\
\text { (Annexin V-/PI-) }\end{array}$ & $95.80 \pm 0.57$ & $89.10 \pm 2.26$ & $86.73 \pm 1.96$ & $91.37 \pm 1.33$ & $72.03 \pm 4.67^{*}$ \\
\hline $\begin{array}{l}\text { Early apoptosis } \\
\text { (Annexin V+/PI-) }\end{array}$ & $2.16 \pm 1.03$ & $1.80 \pm 0.83$ & $8.22 \pm 2.48^{* *}$ & $3.87 \pm 1.22$ & $4.85 \pm 2.05$ \\
\hline $\begin{array}{l}\text { Late apoptosis } \\
(\text { Annexin } \mathrm{V}+/ \mathrm{PI}+)\end{array}$ & $0.90 \pm 0.25$ & $2.56 \pm 1.30$ & $4.92 \pm 0.95^{*}$ & $2.23 \pm 0.67$ & $8.13 \pm 0.06^{* *}$ \\
\hline $\begin{array}{l}\text { Nonapoptotic cells } \\
\text { (Annexin V-/PI+) }\end{array}$ & $1.12 \pm 0.69$ & $6.54 \pm 0.13^{*}$ & $0.14 \pm 0.69$ & $2.52 \pm 0.68$ & $14.93 \pm 0.42^{* *}$ \\
\hline
\end{tabular}

Results are expressed as percentage of total cells. The experiment is expressed as mean \pm standard deviation; significant differences between untreated cells (CT) and cells treated with lycopene $(5-10 \mu \mathrm{M})$ were compared by one-way ANOVA with the posttest of Tukey $\left({ }^{*} p<0.05 ;{ }^{* *} p<0.01\right)$.

RS and UWF cocoa. Figure 4 shows the influence of the extracts of cocoa nibs on the rate of apoptosis. Cells treated with $5 \mathrm{mg} / \mathrm{mL}$ and $10 \mathrm{mg} / \mathrm{mL}$ RS and UWF cocoa for 48 hours resulted in a significant increase in the percentage of apoptotic cells compared with untreated cells (control).
The concentrations used in this cellular model promoted a change in cell cycle and induction of apoptosis by lower doses than isolated compounds or cocoa products used in studies with human models. [55-57]. This has been demonstrated in a study by Ottaviani et al. [57], where adult males were given 


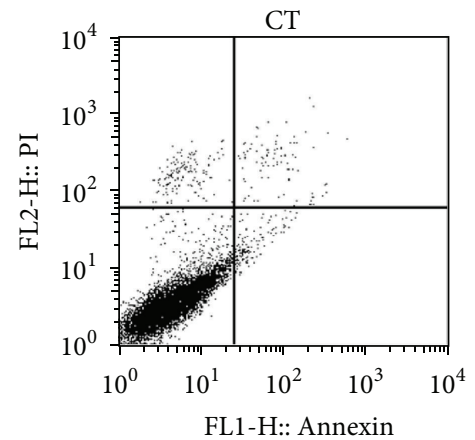

RS
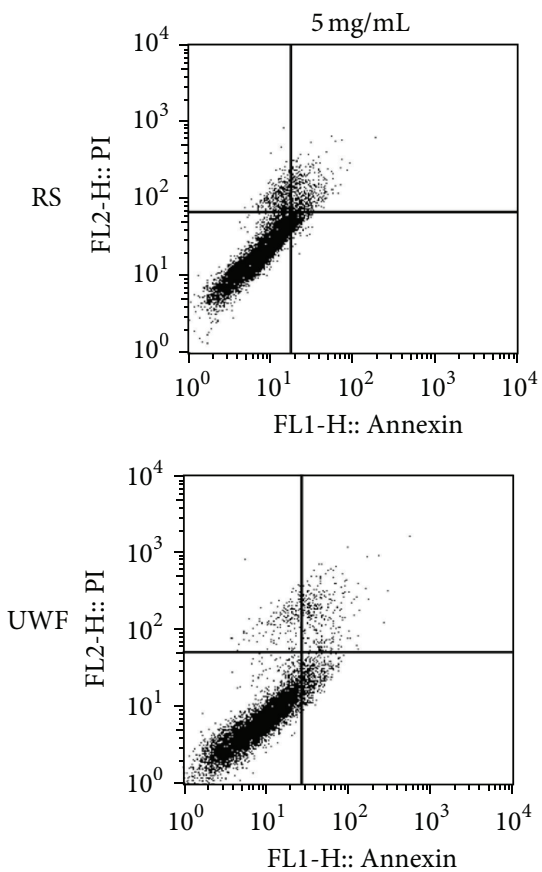

(a)
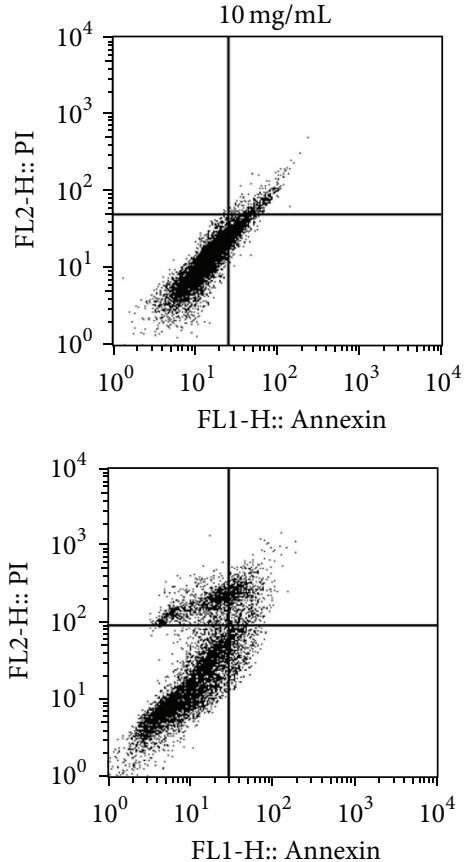

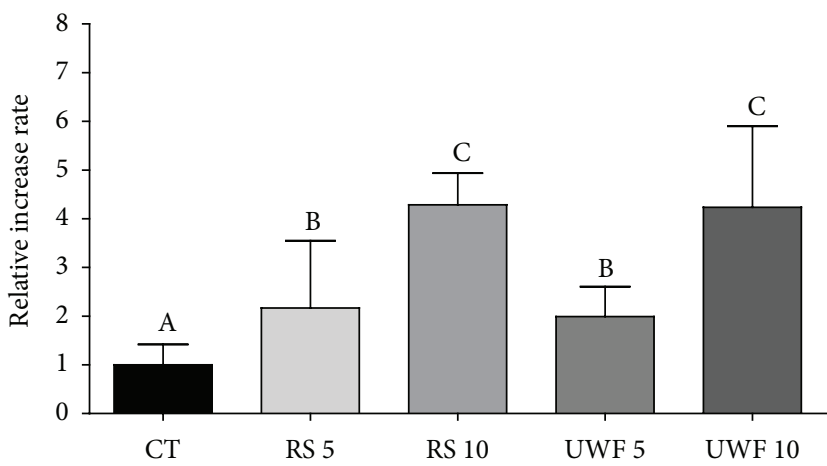

(b)

FiguRE 5: The effect of unroasted well fermented cocoa and roasted slates on the process of programmed death in A549 cells after treatment for $48 \mathrm{~h}$. (a) Flow cytometry analysis of UWF cocoa and RS according to the exposure time and concentration of the compounds. (b) Quantitative effects of UWF cocoa and RS at $5 \mathrm{mg} / \mathrm{mL}$ and $10 \mathrm{mg} / \mathrm{mL}$ on A549 cells after exposure for $48 \mathrm{~h}$. The results are expressed as mean \pm SD, with significant differences between untreated cells (CT) and cells treated with UWF cocoa and RS (5-10 mg/mL) compared by 1-way ANOVA followed by Tukey's multiple comparison post hoc test. ${ }^{*} p<0.05 .{ }^{* *} p<0.01$.

$1.5 \mathrm{mg} / \mathrm{kg}$ of a concentrated cocoa solution, and two hours after ingestion it was noted that there were many metabolites of flavonols in cocoa in the blood of the volunteers.

Increase of early apoptosis was observed in A549 cells treated with $10 \mathrm{mg} / \mathrm{mL}$ RS, whereas increase in late apoptosis was observed in cells treated with $10 \mathrm{mg} / \mathrm{mL}$ UWF cocoa for $48 \mathrm{~h}$. A549 cells incubated with $5 \mathrm{mg} / \mathrm{mL}$ and $10 \mathrm{mg} / \mathrm{mL}$ RS UQG for 48 hours showed a decrease in the population of viable cells and an increase of up to 4.3 times in the percentage of apoptotic cells compared with control, in a dose-dependent manner (Table 2 and Figure 5).

Apoptosis is characterized by a series of distinct changes in cell morphology, loss of cell attachment, cytoplasmic contraction, DNA fragmentation, and other biochemical changes, including the activation of caspases through extrinsic and/or intrinsic mitochondrial pathways [58]. Increased resistance to apoptosis is a hallmark of many tumor cells. The functional inhibition of specific antiapoptotic factors may provide a rational basis for the development of novel therapeutic strategies. Therefore, apoptotic deficiency is considered to be a major cause of therapeutic resistance of tumors, since many chemotherapeutic and radiotherapeutic agents act through the induction of apoptosis [59]. However, the apoptotic effect of the active ingredient of cocoa bean samples on A549 cells has not yet been studied in detail. 


\section{Conclusion}

In conclusion, cocoa extract presented itself as a potent antioxidant agent, with antioxidant capability influenced by the processing method and extraction. Slate cocoa beans extract inhibited cell proliferation, arrested cell cycle in different phases, and increased apoptosis in human lung carcinoma cells, in a time-dependent and dose-dependent manner. Our study has far reaching health relevance as cocoa could be projected as functional foods which, in addition to providing nutrition, would provide preventive therapeutic value against the development of cancer.

\section{Competing Interests}

The authors declare that they have no competing interests.

\section{Acknowledgments}

The authors would like to thank Dr. Osnat Hakimi for her careful reading of the final text and valuable suggestions.

\section{References}

[1] WHO, World Health Statistics 2013, World Health Organization, 2013.

[2] M. Al Zeyadi, I. Dimova, V. Ranchich et al., "Whole genome microarray analysis in non-small cell lung cancer," Biotechnology and Biotechnological Equipment, vol. 29, no. 1, pp. 111-118, 2015.

[3] INCA, Estimativa 2014: Incidência de Câncer no Brasil, Ministério da Saúde, 2014.

[4] M. Ni, X. Shi, Z. Qu, H. Jiang, Z. Chen, and J. Hu, "Epithelial mesenchymal transition of non-small-cell lung cancer cells A549 induced by SPHK1," Asian Pacific Journal of Tropical Medicine, vol. 8, no. 2, pp. 142-146, 2015.

[5] World Cancer Research Fund and American Institute for Cancer Research, Food, Nutrition, Physical Activity, and the Prevention of Cancer: A Global Perspective, 2007.

[6] K. M. Stadler, "The diet and cancer connection," in Extension Specialist, Human Nutrition and Foods, Virginia Tech, 2009.

[7] A. R. Hazirah, B. Zainal, and M. A. Abdah, "Total phenolic content, antioxidant and cytotoxic activity of cocoa (Theobroma cacao L.) polyphenols extracts on cancer cell lines," Malaysian Journal of Nutrition, vol. 19, no. 2, pp. 223-232, 2013.

[8] F. Turati, M. Rossi, C. Pelucchi, F. Levi, and C. La Vecchia, "Fruit and vegetables and cancer risk: a review of southern European studies," British Journal of Nutrition, vol. 113, no. 2, supplement, pp. S102-S110, 2015.

[9] C. Sanbongi, N. Osakabe, M. Natsume, T. Takizawa, S. Gomi, and T. Osawa, "Antioxidative Polyphenols Isolated from Theobroma cacao," Journal of Agricultural and Food Chemistry, vol. 46, no. 2, pp. 454-457, 1998.

[10] W. Ren, Z. Qiao, H. Wang, L. Zhu, and L. Zhang, "Flavonoids: promising anticancer agents," Medicinal Research Reviews, vol. 23, no. 4, pp. 519-534, 2003.

[11] J. Wollgast and E. Anklam, "Review on polyphenols in Theobroma cacao: changes in composition during the manufacture of chocolate and methodology for identification and quantification," Food Research International, vol. 33, no. 6, pp. 423-447, 2000 .
[12] M. Arlorio, M. Locatelli, F. Travaglia et al., "Roasting impact on the contents of clovamide (N-caffeoyl-L-DOPA) and the antioxidant activity of cocoa beans (Theobroma cacao L.)," Food Chemistry, vol. 106, no. 3, pp. 967-975, 2008.

[13] K. B. Miller, W. J. Hurst, M. J. Payne et al., "Impact of alkalization on the antioxidant and flavanol content of commercial cocoa powders," Journal of Agricultural and Food Chemistry, vol. 56, no. 18, pp. 8527-8533, 2008.

[14] M. J. Payne, W. J. Hurst, K. B. Miller, C. Rank, and D. A. Stuart, "Impact of fermentation, drying, roasting, and dutch processing on epicatechin and catechin content of cacao beans and cocoa ingredients," Journal of Agricultural and Food Chemistry, vol. 58, no. 19, pp. 10518-10527, 2010.

[15] C. A. Rice-Evans, N. J. Miller, and G. Paganga, "Antioxidant properties of phenolic compounds," Trends in Plant Science, vol. 2, no. 4, pp. 152-159, 1997.

[16] A. Crozier, D. Del Rio, and M. N. Clifford, "Bioavailability of dietary flavonoids and phenolic compounds," Molecular Aspects of Medicine, vol. 31, no. 6, pp. 446-467, 2010.

[17] H. Osman, R. Nasarudin, and S. L. Lee, "Extracts of cocoa (Theobroma cacao L.) leaves and their antioxidation potential," Food Chemistry, vol. 86, no. 1, pp. 41-46, 2004.

[18] P. Talalay, "Chemoprotection against cancer by induction of Phase 2 enzymes," BioFactors, vol. 12, no. 1-4, pp. 5-11, 2000.

[19] Y.-J. Surh, "Cancer chemoprevention with dietary phytochemicals," Nature Reviews Cancer, vol. 3, no. 10, pp. 768-780, 2003.

[20] K. R. Martin, "Targeting apoptosis with dietary bioactive agents," Experimental Biology and Medicine, vol. 231, no. 2, pp. 117-129, 2006.

[21] V. L. Singleton and J. A. J. Rossi, "Colorimetry of total phenolics with phosphomolybdic-phosphotungstic acid reagents," American Journal of Enology and Viticulture, vol. 16, no. 3, pp. 144-158, 1965.

[22] W. Brand-Williams, M. E. Cuvelier, and C. Berset, "Use of a free radical method to evaluate antioxidant activity," LWT-Food Science and Technology, vol. 28, no. 1, pp. 25-30, 1995.

[23] M. D. S. M. Rufino, R. E. Alves, E. S. De Brito et al., "Metodologia Científica: Determinação da Atividade Antioxidante Total em Frutas pela Captura do Radical Livre," Comunicado Técnico 127, 2007.

[24] M. D. S. M. Rufino, R. E. Alves, E. S. De Brito, S. M. De Morais, C. D. G. Sampaio, and F. D. Saura-Calixto, "Metodologia Científica: Determinação da Atividade Antioxidante Total em Frutas pelo Método de Redução do Ferro (FRAP)," Comunicado Técnico 125, Embrapa Agroindústria Tropical, 2006.

[25] L. L. Vindelov, "Flow microfluorometric analysis of nuclear DNA in cells from solid tumors and cell suspensions. A new method for rapid isolation and staining of nuclei," Virchows Archiv Abteilung B: Cell Pathology, vol. 24, no. 3, pp. 227-242, 1977.

[26] I. E. Dreosti, "Antioxidant polyphenols in tea, cocoa, and wine," Nutrition, vol. 16, no. 7-8, pp. 692-694, 2000.

[27] A. Othman, A. Ismail, N. Abdul Ghani, and I. Adenan, "Antioxidant capacity and phenolic content of cocoa beans," Food Chemistry, vol. 100, no. 4, pp. 1523-1530, 2007.

[28] Z. Benayad, C. Martinez-Villaluenga, J. Frias, C. GomezCordoves, and N. E. Es-Safi, "Phenolic composition, antioxidant and anti-inflammatory activities of extracts from Moroccan Opuntia ficus-indica flowers obtained by different extraction methods," Industrial Crops and Products, vol. 62, pp. 412-420, 2014. 
[29] V. J. Cheng, A. E.-D. A. Bekhit, M. McConnell, S. Mros, and J. Zhao, "Effect of extraction solvent, waste fraction and grape variety on the antimicrobial and antioxidant activities of extracts from wine residue from cool climate," Food Chemistry, vol. 134, no. 1, pp. 474-482, 2012.

[30] L. Boulekbache-Makhlouf, L. Medouni, S. Medouni-Adrar, L. Arkoub, and K. Madani, "Effect of solvents extraction on phenolic content and antioxidant activity of the byproduct of eggplant," Industrial Crops and Products, vol. 49, pp. 668-674, 2013.

[31] D. Kadow, N. Niemenak, S. Rohn, and R. Lieberei, "Fermentation-like incubation of cocoa seeds (Theobroma cacao L.) - reconstruction and guidance of the fermentation process," LWT-Food Science and Technology, vol. 62, no. 1, pp. 357-361, 2015.

[32] S. Elwers, A. Zambrano, C. Rohsius, and R. Lieberei, "Differences between the content of phenolic compounds in Criollo, Forastero and Trinitario cocoa seed (Theobroma cacao L.)," European Food Research and Technology, vol. 229, no. 6, pp. 937948, 2009.

[33] Q. R. Araujo, C. A. F. Fernandes, D. O. Ribeiro et al., "Cocoa quality index-a proposal," Food Control, vol. 46, pp. 49-54, 2014.

[34] A. Krähmer, A. Engel, D. Kadow et al., "Fast and neatdetermination of biochemical quality parameters in cocoa using near infrared spectroscopy," Food Chemistry, vol. 181, pp. 152159, 2015.

[35] E. O. Afoakwa, E. Ofosu-Ansah, J. F. Takrama, A. S. Budu, and H. Mensah-Brown, "Changes in chemical quality of cocoa butter during roasting of pulp pre-conditioned and fermented cocoa (Theobroma cacao) beans," International Food Research Journal, vol. 21, no. 6, pp. 2221-2227, 2014.

[36] E. O. Afoakwa, A. Paterson, M. Fowler, and A. Ryan, "Flavor formation and character in cocoa and chocolate: a critical review," Critical Reviews in Food Science and Nutrition, vol. 48, no. 9, pp. 840-857, 2008.

[37] Y. Suazo, G. Davidov-Pardo, and I. Arozarena, "Effect of fermentation and roasting on the phenolic concentration and antioxidant activity of cocoa from nicaragua," Journal of Food Quality, vol. 37, no. 1, pp. 50-56, 2014.

[38] J. M. Silván, J. van de Lagemaat, A. Olano, and M. D. del Castillo, "Analysis and biological properties of amino acid derivates formed by Maillard reaction in foods," Journal of Pharmaceutical and Biomedical Analysis, vol. 41, no. 5, pp. 15431551, 2006.

[39] H.-Y. Wang, H. Qian, and W.-R. Yao, "Melanoidins produced by the Maillard reaction: structure and biological activity," Food Chemistry, vol. 128, no. 3, pp. 573-584, 2011.

[40] R. Apak, K. Güçlü, M. Özyürek, and S. E. Karademir, "Novel total antioxidant capacity index for dietary polyphenols and vitamins $\mathrm{C}$ and $\mathrm{E}$, using their cupric ion reducing capability in the presence of neocuproine: CUPRAC method," Journal of Agricultural and Food Chemistry, vol. 52, no. 26, pp. 7970-7981, 2004.

[41] T. L. C. Oldoni, Prospecção e identificação de compostos bioativos de subprodutos agroindustriais [Ph.D. thesis], Universidade de São Paulo, 2010.

[42] E. de Almeida Melo, M. I. S. Maciel, V. L. A. G. de Lima, and R. J. do Nascimento, "Capacidade antioxidante de frutas," Revista Brasileira de Ciências Farmacêuticas, vol. 44, no. 2, 2008.

[43] G. Skrede, R. E. Wrolstad, R. W. Durst, and G. Skrede, “Changes in Anthocyanins and Polyphenolics During Juice Processing of
Highbush Blueberries (Vaccinium corymbosum L," J. Food Sci, vol. 65, no. 2, pp. 357-364, 2000.

[44] M. Vizzotto and M. C. Pereira, "Amora-preta (Rubus sp.): otimização do processo de extração para determinação de compostos fenólicos antioxidantes," Revista Brasileira de Fruticultura, vol. 33, no. 4, pp. 1209-1214, 2011.

[45] Y. Yilmaz and R. T. Toledo, "Oxygen radical absorbance capacities of grape/wine industry byproducts and effect of solvent type on extraction of grape seed polyphenols," Journal of Food Composition and Analysis, vol. 19, no. 1, pp. 41-48, 2006.

[46] A. B. Granado-Serrano, M. A. Martín, G. Haegeman, L. Goya, L. Bravo, and S. Ramos, "Epicatechin induces NF- $\kappa$ B, activator protein-1 (AP-1) and nuclear transcription factor erythroid 2p45-related factor-2 (Nrf2) via phosphatidylinositol3-kinase/protein kinase B (PI3K/AKT) and extracellular regulated kinase (ERK) signalling in HepG2 cells," British Journal of Nutrition, vol. 103, no. 2, pp. 168-179, 2010.

[47] N. J. Kang, K. W. Lee, D. E. Lee et al., "Cocoa procyanidins suppress transformation by inhibiting mitogen-activated protein kinase kinase," The Journal of Biological Chemistry, vol. 283, no. 30, pp. 20664-20673, 2008.

[48] L. Valdés, A. Cuervo, N. Salazar, P. Ruas-Madiedo, M. Gueimonde, and S. González, "The relationship between phenolic compounds from diet and microbiota: impact on human health," Food Funct., vol. 6, no. 8, pp. 2424-2439, 2015.

[49] B. P. Soule, N. L. Simone, W. G. DeGraff, R. Choudhuri, J. A. Cook, and J. B. Mitchell, "Loratadine dysregulates cell cycle progression and enhances the effect of radiation in human tumor cell lines," Radiation Oncology, vol. 5, no. 1, article 8, 2010.

[50] N. da Costa Pereira Soares, A. J. Teodoro, F. L. Oliveira et al., "Lycopene induce apoptosis in human prostate cells and alters the expression of Bax and Bcl-2 genes," LWT-Food Science and Technology, vol. 59, no. 2, pp. 1290-1297, 2014.

[51] D. Ramljak, L. J. Romanczyk, L. J. Metheny-Barlow et al., "Pentameric procyanidin from Theobroma cacao selectively inhibits growth of human breast cancer cells," Molecular Cancer Therapeutics, vol. 4, no. 4, pp. 537-546, 2005.

[52] S. Carnésecchi, Y. Schneider, S. A. Lazarus, D. Coehlo, F. Gossé, and F. Raul, "Flavanols and procyanidins of cocoa and chocolate inhibit growth and polyamine biosynthesis of human colonic cancer cells," Cancer Letters, vol. 175, no. 2, pp. 147-155, 2002.

[53] X. Tan, D. Hu, S. Li, Y. Han, Y. Zhang, and D. Zhou, "Differences of four catechins in cell cycle arrest and induction of apoptosis in LoVo cells," Cancer Letters, vol. 158, no. 1, pp. 1-6, 2000.

[54] L. D. Murad, C. P. da Soares, C. Brand, M. C. Monteiro, and A. J. Teodoro, "Effects of caffeic and 5-caffeoylquinic acids on cell viability and cellular uptake in human colon adenocarcinoma cells," Nutrition and Cancer, vol. 67, no. 3, pp. 532-542, 2015.

[55] J. I. Ottaviani, T. Y. Momma, C. Heiss, C. Kwik-Uribe, H. Schroeter, and C. L. Keen, "The stereochemical configuration of flavanols influences the level and metabolism of flavanols in humans and their biological activity in vivo," Free Radical Biology and Medicine, vol. 50, no. 2, pp. 237-244, 2011.

[56] K. Neukam, W. Stahl, H. Tronnier, H. Sies, and U. Heinrich, "Consumption of flavanol-rich cocoa acutely increases microcirculation in human skin," European Journal of Nutrition, vol. 46, no. 1, pp. 53-56, 2007.

[57] J. I. Ottaviani, T. Y. Momma, G. K. Kuhnle, C. L. Keen, and H. Schroeter, "Structurally related (-)-epicatechin metabolites in humans: assessment using de novo chemically synthesized authentic standards," Free Radical Biology and Medicine, vol. 52, no. 8, pp. 1403-1412, 2012. 
[58] H. S. Tuli, S. S. Sandhu, A. K. Sharma, and P. Gandhi, "Antiangiogenic activity of the extracted fermentation broth of an entomopathogenic fungus, Cordyceps militaris 3936," International Journal of Pharmacy and Pharmaceutical Sciences, vol. 6, no. 7, pp. 581-583, 2014.

[59] A. J. Teodoro, F. L. Oliveira, N. B. Martins, G. D. A. Maia, R. B. Martucci, and R. Borojevic, "Effect of lycopene on cell viability and cell cycle progression in human cancer cell lines," Cancer Cell International, vol. 12, no. 1, article 36, 2012. 


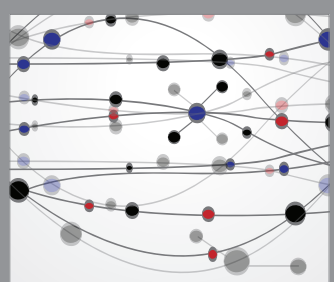

The Scientific World Journal
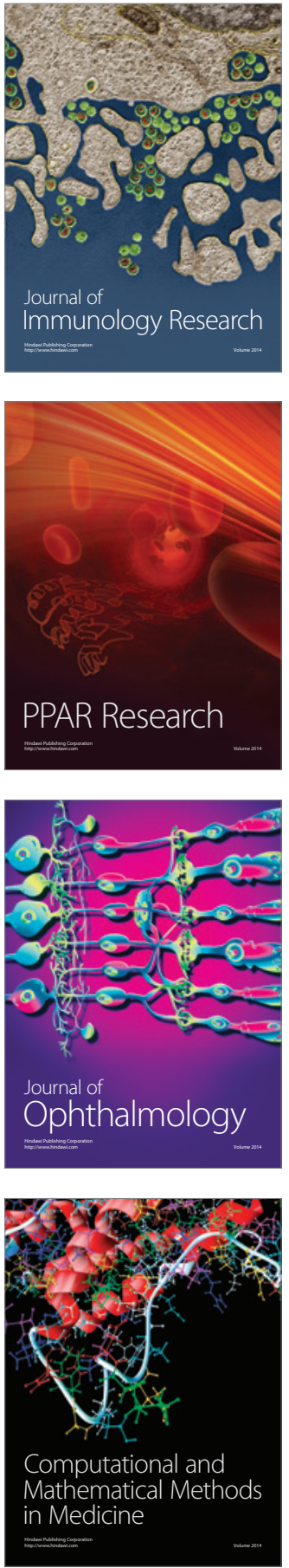

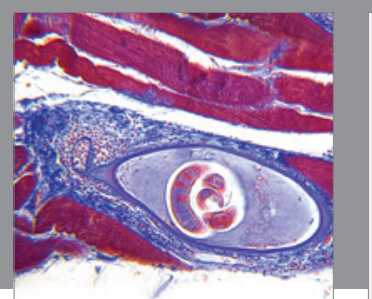

Gastroenterology Research and Practice

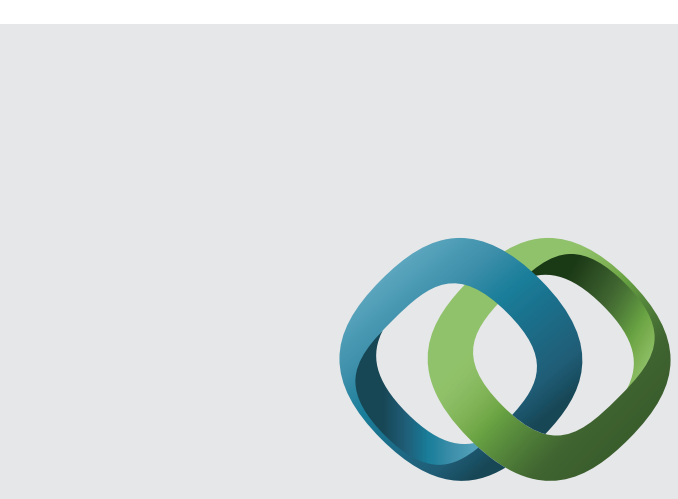

\section{Hindawi}

Submit your manuscripts at

http://www.hindawi.com
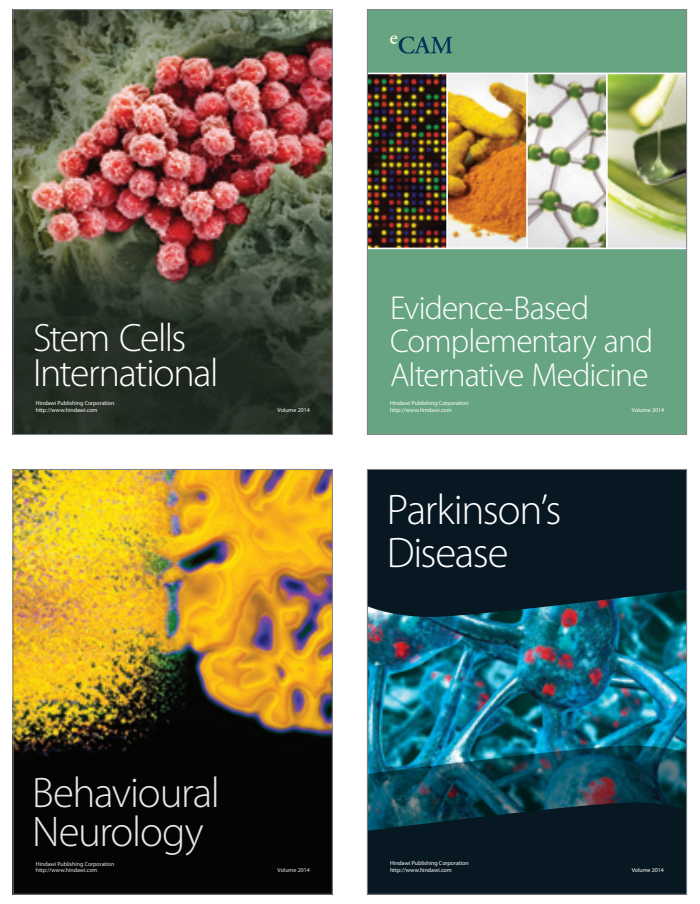
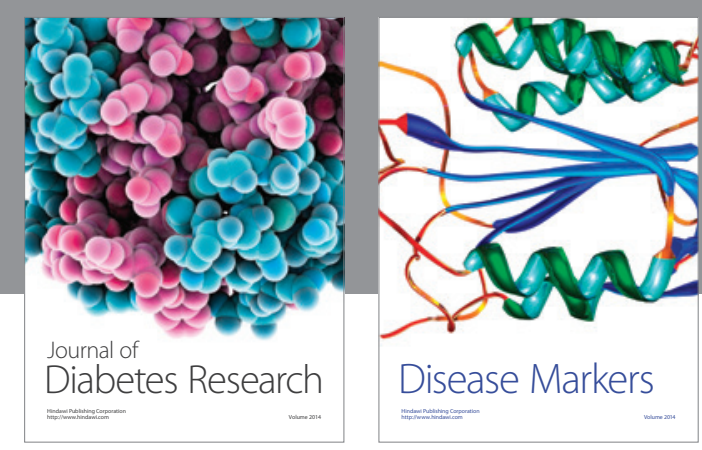

Disease Markers
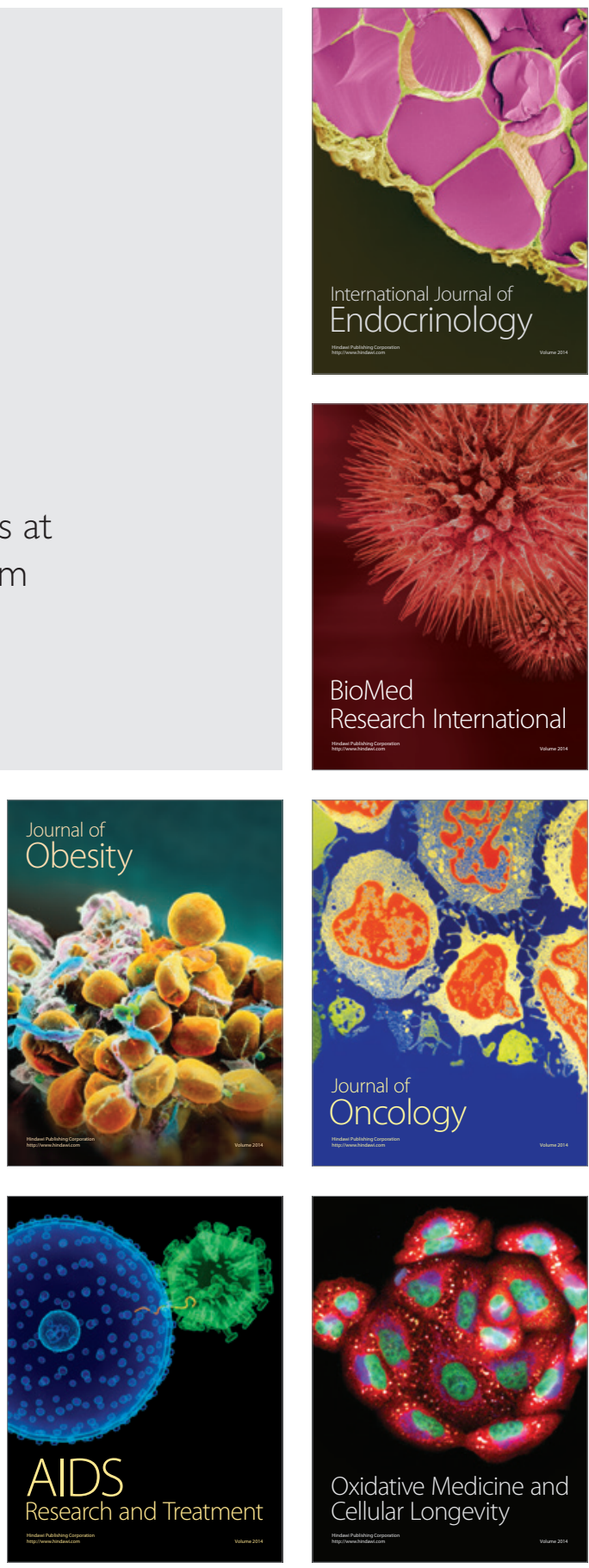